Relations industrielles

Industrial Relations

\title{
Robert P. VECCHIO : Organizational Behavior. Chicago, Toronto, The Dryden Press, 1988, 576 pp., ISBN 0-000853-0
}

\section{Bernard Portis}

Volume 44, numéro 4, 1989

URI : https://id.erudit.org/iderudit/050551ar

DOI : https://doi.org/10.7202/050551ar

Aller au sommaire du numéro

Éditeur(s)

Département des relations industrielles de l'Université Laval

ISSN

0034-379X (imprimé)

1703-8138 (numérique)

Découvrir la revue

Citer ce compte rendu

Portis, B. (1989). Compte rendu de [Robert P. VECCHIO : Organizational

Behavior. Chicago, Toronto, The Dryden Press, 1988, 576 pp., ISBN 0-000853-0].

Relations industrielles / Industrial Relations, 44(4), 963-964.

https://doi.org/10.7202/050551ar

Tous droits réservés @ C Département des relations industrielles de l'Université Laval, 1989
Ce document est protégé par la loi sur le droit d'auteur. L'utilisation des services d'Érudit (y compris la reproduction) est assujettie à sa politique d'utilisation que vous pouvez consulter en ligne.

https://apropos.erudit.org/fr/usagers/politique-dutilisation/ 
chapitre illustre une démarche d'implantation d'un programme de QVT et relate les stratégies, les difficultés et les implications d'un tel projet. Le dernier chapitre étudie la relation entre l'excellence et la QVT telle qu'expliquée dans les chapitres précédents. À ce titre, l'auteur croise chacun des huit attributs de l'excellence et les dimensions d'un programme de QVT.

En synthèse, le livre est constitué de deux pôles dont le premier, centré sur la notion de QVT, constitue près de $80 \%$ du volume (chap. 2, 3, 4, 5,6). Le second pôle, qui est l'objet du septième chapitre, établit la relation entre la QVT et l'excellence organisationnelle.

De façon concrète, l'ouvrage est une réflexion globale sur le concept de QVT. Ceci est d'autant plus intéressant que cette notion a souvent été présentée soit à travers des études de cas isolés faute d'une formulation synthèse ou soit de façon tellement théorique qu'elle n'est pas opérationnelle. L'originalité de Pierre Turcotte réside dans la mise en évidence des liens qui existent entre les huit attributs de l'excellence et les dimensions d'un programme de QVT (participation, communications, environnement de travail et design des tâches, voir tableau 7.2, p. 240). Cette relation est basée sur des considérations générales découlant d'une compréhension globale du concept de QVT qui préconise la réorganisation du travail de manière à favoriser la participation, le bien-être du travailleur et l'harmonisation du milieu de travail et de l'environnement hors travail. Par contre, en ce qui concerne la notion d'excellence, l'auteur se contente de faire simplement référence à la conception managériale de Peters et Waterman qui est un ensemble de principes. D'emblée, il devient relativement facile, voire évident, de conclure que toute organisation qui adopte une approche de QVT ne peut que tendre vers l'excellence, ce qui est vrai en principe, sauf que dans les faits, certaines questions restent sans réponse. Par exemple, on peut se demander pourquoi si peu d'entreprises, particulièrement les PME québécoises, adoptent cette approche, surtout quand elles peuvent espérer devenir excellentes. Pourquoi y a-t-il autant de programmes de QVT qui échouent ou sont arrêtés après quelques années? À notre avis, la dimension critique de la relation entre la QVT et l'excellence organisationnelle a été très peu mise en relief. Ce n'était peut-être pas la préoccupation immédiate de l'auteur qui, nous en sommes convaincu, est très certainement conscient des difficultés de réalisation d'un programme de QVT et des embûches qui parsèment le chemin de l'excellence.

En conclusion, l'ouvrage reste un outil d'éveil et de sensibilisation aux vertus de la QVT comme philosophie de gestion. En tant que tel, il peut certainement susciter l'émergence d'une culture de QVT comme un concept global lié à toute forme d'organisation et non pas comme un simple courant de pensée que certains considèrent déjà dépassé. Selon la perspective de ce livre, la ressource humaine reste la clef de survie des entreprises dans le contexte actuel de déréglementation de l'environnement économique et il est primordial de lui assurer une meilleure qualité de vie au travail.

Roger ZAORÉ

Université du Québec à Rimouski

Organizational Behavior, by Robert P. Vecchio, Chicago, Toronto, The Dryden Press, 1988, pp. 576, ISBN 0-000853-0

This textbook is a useful introduction to the research conducted on individual behavior in organizations. The first thirteen chapters present findings and conceptual schemes developed mainly by academic researchers in relation to topics of practical importance, such as learning, motivation, performance appraisal, leadership, group dynamics and stress. 
The last four chapters are concerned with organizational structure and processes, including such topics as communication, organizational design and organizational change. In these four chapters fewer research studies are cited and there is more reliance on writings of organizational consultants. This indicates that much research needs to be done.

This textbook is directed toward the beginning student and each chapter starts with a short case or magazine article describing how particular topics such as leadership or communication actually occur in organizations. These introductory examples are more interesting than the various frameworks developed in academic research. Introductory students in business administration might benefit more from books with cases and readings as the cases would be much expanded and the articles present fewer conceptual frameworks in greater depth.

Practicing managers should read books like this to get greater understanding of how they can better communicate with employees and generally make their organizations more effective. The managers should start with the final four chapters to determine which particular topics in organizational practice have greatest interest to them. For example they might be interested in how to use quality of work life (QWL) as a tool in organizational development. They would find references to early chapters on job design, decision making and group dynamics. It would be very wise to read these other chapters before deciding whether to start a QWL program in a company.

In summary, the current urgency to get greater participation and effectiveness from both managers and employees makes all this academic research and conceptual schemes more useful. Organizational behavior is definitely a field whose time has come.

Bernard PORTIS

The University of Western Ontario

Designing Effective Organizations. The Sociotechnical Systems Perspective, by William A. Pasmore, Wiley Series on Organizational Assessment and Change, New York, John Wiley, 1988, pp. $x+200$, ISBN 0-471-88785-4

This book deals with the question how well the social and technical systems are designed with respect to one another and with respect to the demands of the external environment. Organizations are agreements among people. "Changes in the organization will affect these agreements and vice-versa” (p. 5).

Environment is treated as a source of provocation and inspiration. The stronger this provocation, the more likely it is that a design will fail to respond adequately to it. The more growth of environmental turbulence, the more flexibility of design is needed. The more evident is the environmental provocation, the more adaptation will be focused on immediate problems. Changes through innovations are the testimony of organizations viewing the environment as the source of inspiration. The growth of external turbulence necessitates to transform the environment as well as the organization. An effective change of the environment necessitates the organizational actions to be at least as powerful as the forces that originally created the environment. In order to adapt to environmental demands, organizations must first be able to determine that demands exist and to distinguish which require response and which do not; reacting to demands may be so as they are presented or transforming the environment so as to eliminate or alter the demands. Responses to changes in the environment require resources proportionate to the significance of the changes. Environmental sensing devices should be at least as sensitive as the context which needs to be understood. The more sensitive the environmental 